\title{
Microwave-Assisted Pyrolysis of Cashew Nut Shell
}

\author{
Novriany Amaliyah*, Andi Erwin Eka Putra
}

Mechanical Engineering Department, Faculty of Engineering, Hasanuddin University, Jl. Malino, Borongloe, Bontomarannu, Kabupaten Gowa, Sulawesi Selatan 92119, Indonesia

Corresponding Author Email: novriany@unhas.ac.id

https://doi.org/10.18280/ijdne.160213

Received: 24 December 2020

Accepted: 6 April 2021

\section{Keywords:}

cashew nutshell, microwave, pyrolysis

\begin{abstract}
This research examines the characteristics of microwave assisted pyrolysis products of cashew nutshell waste (CNS). The pyrolysis process of CNS conducted with microwave heating of $400 \mathrm{~W}$ for 60 minutes. Pyrolysis product such as bio-gas, bio-oil and bio-char were identified using proximate and ultimate analysis, scanning electron microscope (SEM), thermogravimetric analysis (TGA/DTG), gas chromatograph-mass spectrometer (GC-MS) and Fourier Transform InfraRed (FTIR) Method. There is a significant increasing in volatile matter and fixed carbon of derived bio-char and the porous structure was observed in a range of macropore after pyrolysis. The TGA profile reveals CNS sample lost about $71.25 \%$ of mass before reached $750^{\circ} \mathrm{C}$. The highest decomposition rate on the DTG profile was $0.57 \mathrm{mg} / \mathrm{min}$ and $0.56 \mathrm{mg} / \mathrm{min}$ as observed at about $261.2^{\circ} \mathrm{C}$ and $340.3^{\circ} \mathrm{C}$. Bio-oil yield has density of $1.036 \mathrm{gr} / \mathrm{ml}$, viscosity of $19.5 \mathrm{cst}$ after water removing, flash point of $138^{\circ} \mathrm{C}$ and $\mathrm{HHV}$ of $21.7 \mathrm{MJ} / \mathrm{kg}$. The GC-MS of the bio-oil shows about $53 \%$ phenol, $19 \%$ palmitic and oleic acid, $11 \%$ cyclobutene, $14 \%$ ethyl and methyl ester, and cyclopentene and cyclohexane in small amounts in accordance with FT-IR results.
\end{abstract}

\section{INTRODUCTION}

The use of renewable energy in the world for the past decade has increased, especially in power plants and other installations [1]. In addition, $13.5 \%$ of world total energy supply (TES) of 14.282 Mtoe was generated from renewable nhji9menergy in 2018, where about $2 \%$ of the average annual rate of renewable energy sources was slightly higher than the growth rate of TES of $1.8 \%$ [2]. Biomass with abundant feedstock is the largest source of renewable energy and expected to play a substantial role in future energy systems [2, 3]. In $2017,86 \%$ of 55.6 EJ biomass utilized biosolids, while bioliquids, and biogases and wastes account for $7 \%$ and $2-$ $3 \%$, respectively [3].

The main economical technology to engineer of biomass is combustion process to produce heat and power. The combustion of biomass depends on its component which is cellulose, hemicellulose, and lignin as the main components, and protein, sugar and aliphatic acids, and fats as the minor components [4]. However, low heating value, high moisture content, and low bulk density is disadvantage of direct burning of raw biomass and it can increase the cost of co firing with coal, especially ash disposal $[5,6]$. The high heating value (HHV) of 20 biomass samples were investigated in the range $15.41-19.52 \mathrm{MJ} / \mathrm{kg}$ and the proximate analysis resulted of the moisture and the ash content in the range $1.25-12.50 \%$ and $1.04-8.98 \%$, respectively [7]. Thermochemical as one of the concepts to improve the quality of raw biomass has been researched extensively in the past decade [8-10]. Pyrolysis is a thermochemical process for decomposing raw biomass at high temperature in the absence of oxygen [11]. In addition, pyrolysis also applied in hazardous waste treatment [12] and choir fiber treatment by the in-liquid plasma method [13], choir fiber treatment using microwave oven as heating source [14] and carbon activation from tires waste with conventional pyrolysis method [15].

For a more sustainable and profitable optimization biomass, pyrolysis can convert into high heating value and bulk density of biosolids (bio-char) and decreasing its moisture and ash contents. Not only biochar but also bioliquids and biogases can be generated by pyrolysis. The quality and quantity of pyrolysis conversion results depend on biomass feedstocks and operating parameters. Conventional pyrolysis method of biomass conversion has been widely studied with different biomass type. 17 - 38\% wt of bio-char yield with $17.60-23.41$ $\mathrm{MJ} / \mathrm{kg}$ of HHV was carried out from 125, 250, and 500 grams of rice husk using slow pyrolysis method in a fixed bed reactor with variations in heating rates of $5,10,20^{\circ} \mathrm{C} / \mathrm{min}$, reactor temperature of $300,400,500^{\circ} \mathrm{C}$, and variations in residence time of 3600, 5400, and $7200 \mathrm{~s}$ [16]. This study has also informed the efficient and thermally feasible bio-char production at a capacity of $500 \mathrm{~g}$ in $400^{\circ} \mathrm{C}$ of fixed bed reactor with $1200 \mathrm{kWh}$, heating rate $10^{\circ} \mathrm{C} / \mathrm{min}$, and residence time of 3600 s. Bio-char and bioliquid (bio-oil) have also been simultaneously generated with a fast pyrolysis of corn cob (HHV $17.8 \mathrm{MJ} / \mathrm{kg}$ ) and stover (HHV $18.3 \mathrm{MJ} / \mathrm{kg}$ ) in a bubbling fluidized bed of quartz at a temperature of $500^{\circ} \mathrm{C}$ [17]. About $60 \%$ (mass $/$ mass) of the bio-oil with about $20 \mathrm{MJ} / \mathrm{kg}$ of $\mathrm{HHV}, 17-19 \%$ of bio-char (HHV $30 \mathrm{MJ} / \mathrm{kg}$ for corn cob and $21 \mathrm{MJ} / \mathrm{kg}$ for stover), and $20-21 \%$ of non-condensable gas were yield in this process.

Meanwhile, in terms of feedstocks biomass, utilization of agricultural waste has also attracted attention. Cashew nut shell (CNS) have great potential as biomass feedstock. $20 \%$ of 
the approximately 4 million tons of cashew nut production in the world is estimated CNS waste with HHV $20.7 \mathrm{MJ} / \mathrm{kg}$ [18]. Slow pyrolysis at 50 grams of 60 mesh CNS has been yield of $30 \%$ wt bio-char, $40 \%$ wt bio-oil, and $30 \%$ wt bio-gas. Biochar products contain $70-75 \%$ carbon content and HHV $25-$ $28 \mathrm{MJ} / \mathrm{kg}$ and $32 \mathrm{MJ} / \mathrm{kg}$ of bio-oil $\mathrm{HHV}$, and dominant $\mathrm{CO}$ dan $\mathrm{CO}_{2}$ content in gas product at lower than $400^{\circ} \mathrm{C}$ were also generated [18]. The thermal behaviors and characteristics of CNS pyrolysis have also been carried out $[19,20]$.

In recent years, $2.45 \mathrm{GHz}$ microwaves as heat sources have been optimized to increase operating parameters in the pyrolysis process. The dielectric heating process of microwaves can streamline the biomass pyrolysis process by reducing energy consumption and reaction processing time, so that this process can improve the overall quality of production [21-23]. Therefore, this research was conducted to produce bio-char and bio-oil with a modified microwave oven as the heat source.

\section{EXPERIMENTAL PROCEDURES}

The CNS was collected from Kendari, Southeast Sulawesi, Indonesia. CNS is dried in an oven at about $60^{\circ} \mathrm{C}$ for 20 minutes and sieved to 10 mesh and 150 grams of CNS is fed into the reactor as shown in Figure 1. Then, the air in the reactor is expelled through a vacuum process in the reactor along with a heating process with microwave oven to $100^{\circ} \mathrm{C}$ to avoid gasification to an appreciable extent. The reactor was equipped with temperature sensor as well as the control of microwave power, reaction time and temperature.

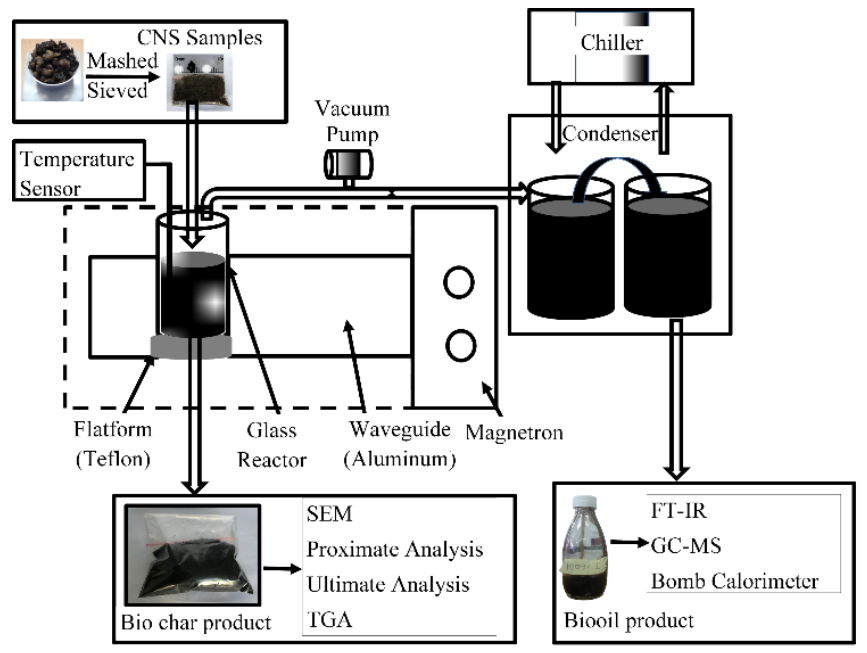

Figure 1. Experimental apparatus

The microwave assisted pyrolysis process is continued for 60 minutes with a power of $400 \mathrm{~W}$. The content of CNS and bio-char production is characterized using proximate and ultimate analysis, Scanning Electron Microscope (SEM), and Thermogravimetric Analysis (TGA) Methods. Proximate analysis for moisture content, ash, volatile matter and fixed carbon are ASTM D 3173-17, ASTM D 3174-12, ASTM D 3175-17, and ASTM D 3172-13, respectively. Bomb calorimeter is used to identify high heating value (HHV) of CNS, bio-char and bio-oil production with ASTM D 5865-13 method. In addition, ultimate analysis for carbon, hydrogen and nitrogen are ASTM D 5373-16 methods. Oxygen and sulfur are identified with ASTM D 3176-15 and ASTM D
4239-18 Method A. Bio-oil is characterized to determine flash point (ASTM 92), density (ASTM D1217), viscosity (ASTM D445), Fourier Transform InfraRed Method (FT-IR), and gas chromatograph-mass spectrometer (GC-MS).

\section{RESULTS AND DISCUSSION}

The pyrolysis process of CNS with microwave heating of $400 \mathrm{~W}$ for 60 minutes is shown in Figure 2. In the first 10 minutes, the temperature rises rapidly at rate of $20{ }^{\circ} \mathrm{C} / \mathrm{min}$ to about $250^{\circ} \mathrm{C}$. The temperature fluctuation is mainly observed in microwave assisted pyrolysis due to the non-uniformity of microwave irradiation, microwave intensity, interference of vapor and slack response. Bio-gas and bio-oil are started to be produced at around $150^{\circ} \mathrm{C}$ and $250^{\circ} \mathrm{C}$, respectively. The reactor temperature continues to increase up to about $420^{\circ} \mathrm{C}$ in 40 minutes at about $5^{\circ} \mathrm{C} / \mathrm{min}$ and gradually decreases to about $370^{\circ} \mathrm{C}$ at the end of the process. The bio-gas and bio-oil production takes about 20 - 30 minutes, bio-gas production was released into the environment. Bio-oil production. The resulting bio-oil is collected in a series of 2 glass placed in a condensation vessel with $10^{\circ} \mathrm{C}$ of circulating water. Meanwhile, bio-char production remains in the pyrolysis reactor.

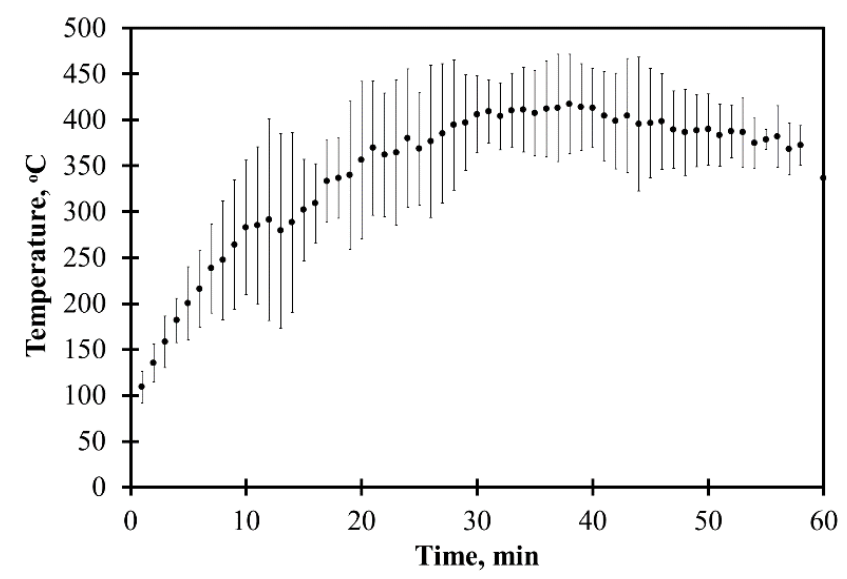

Figure 2. History of reactor temperature during the pyrolysis process. Error bars represent $95 \%$ confidence level

Bio-char and bio-oil production from the pyrolysis process of 150 grams of CNS with $9.4 \%$ water content are about $35 \%$ and $45 \%$, respectively, and about $20 \%$ of the by-products are water and bio-gas. Table 1 shows the proximate and ultimate analysis of CNS and a significant increase in volatile matter and fixed carbon of bio-char production. However, Ash content of bio-char production also slightly increase and moisture content of biochar production decrease. Theoretically, the stoichiometric air requirement of bio-char combustion is slightly higher than CNS. Bio-char present decreasing contents of moisture, volatile matter and oxygen and increasing contents of carbon, fixed carbon, and ash. These trends seem to be consistent with other research reported in the literature [24, 25].

The HITACHI FLEXSEM 100 was used for Scanning Electron Microscope (SEM) to evaluate the morphology of bio-char. The pore surface structure of the bio-chars with magnification of 2000 times and 10000 times is presented in Figure 3. 
Table 1. Proximate and ultimate analysis of CNS and biochar production

\begin{tabular}{lcc}
\hline \multicolumn{1}{c}{ Proximate } & CNS & $\begin{array}{c}\text { Bio-char } \\
\text { production }\end{array}$ \\
\hline Moisture (\%) & 9.4 & 1.5 \\
Ash (\%) & 1.9 & 4.0 \\
Volatile Matter (\%) & 74.8 & 62.4 \\
Fixed Carbon (\%) & 13.9 & 32.1 \\
\hline \multicolumn{1}{c}{ Ultimate } & \multicolumn{2}{c}{} \\
\hline $\mathrm{C}(\%)$ & 51 & 68.7 \\
$\mathrm{H}(\%)$ & 6.9 & 5.4 \\
$\mathrm{~N}(\%)$ & 0.5 & 0.9 \\
$\mathrm{O}(\%)$ & 39.5 & 20.9 \\
$\mathrm{~S}(\%)$ & 0.06 & 0.07 \\
Unidentified (\%) & 1.9 & 4.0 \\
\hline HHV (MJ/kg) & 22.5 & 30.6 \\
\hline Theoretical air requiremei & $7.3 \mathrm{~kg}$ air $/ \mathrm{kg}$ & $9 \mathrm{~kg}$ air $/ \mathrm{kg} \mathrm{bio-}$ \\
for combustion & $\mathrm{CNS}$ & char \\
\hline
\end{tabular}

SEM image of untreated CNS was reported appears to be irregular and porous [26-28]. Pyrolysis treatment changes the surface structure of CNS from irregular and small particles become smoother and more porous structure were noticed. Previous research has reported that through pyrolysis, volatile organic compounds are generated which influence the porous structure of the final bio-chars $[22,26,28]$. The porous structure of derived bio-char using microwave-assisted pyrolysis covers the range of macropore $(>50 \mathrm{~nm})$.

Figure 4 shows the TGA and DTG curves for raw CNS and bio-char produced. TGA and DTG analysis were conducted in the $\mathrm{N}_{2}$ gas atmosphere at the temperature of $30-750^{\circ} \mathrm{C}$. TGA profile shows the mass percentage reduction versus temperature while DTG profile determines the reduction of mass per time versus temperature. The TGA profile reveals CNS sample lost about $71.25 \%$ of mass before reached $750^{\circ} \mathrm{C}$ through three decomposition stages. The first stage occurred at the temperature of $150^{\circ} \mathrm{C}$ with a mass decrease of $6.22 \%$ through the evaporation of moisture content. The highest mass loss of $58.3 \%$ in the second stage at the temperature of 350 $400^{\circ} \mathrm{C}$. Pyrolysis with $\mathrm{CH}_{2} \mathrm{Cl}_{2}$ reported extracted only $31 \%$ of the original CNS [29]. The highest decomposition rate on the DTG profile was $0.57 \mathrm{mg} / \mathrm{min}$ and $0.56 \mathrm{mg} / \mathrm{min}$ as observed at about $261.2^{\circ} \mathrm{C}$ and $340.3^{\circ} \mathrm{C}$ respectively that indicating a broad peak. DTG peak of CNS also reported in a range of 250 $400^{\circ} \mathrm{C}$ in a conventional pyrolysis $[29,30]$. Some partial evaporation take place at temperature higher than $300^{\circ} \mathrm{C}$ and it is assumed due to the high boiling point of liquid in CNS compound. This condition also reported by some author at similar temperature [31-33].

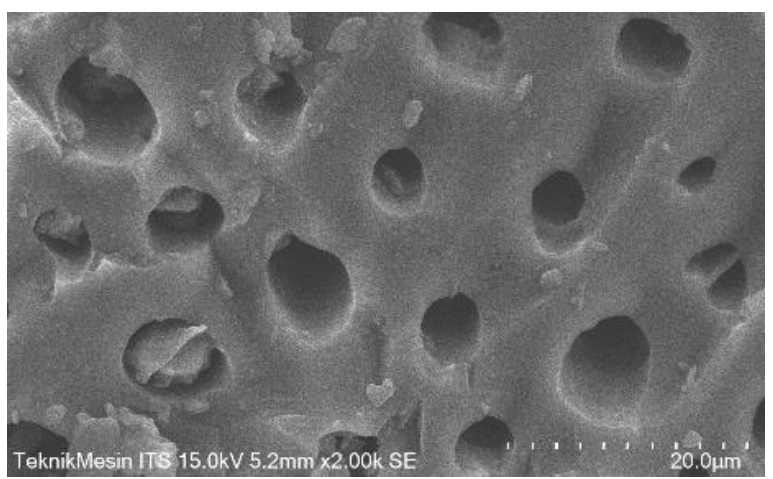

(a)

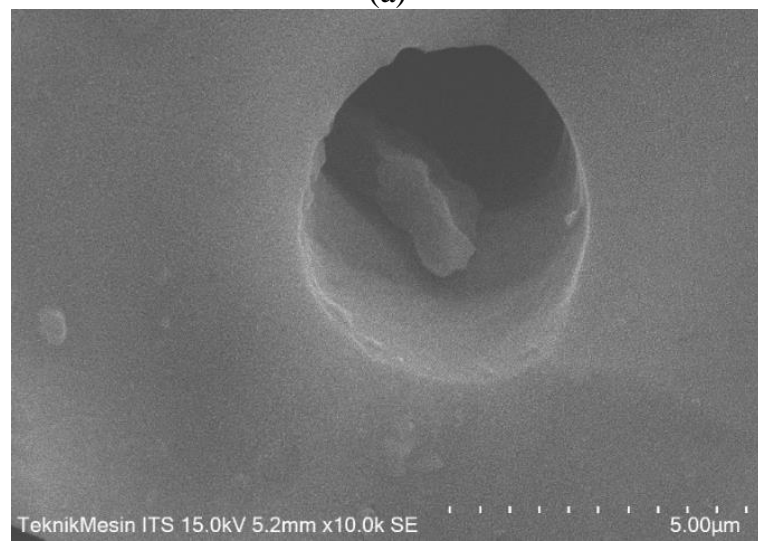

(b)

Figure 3. SEM picture of bio-char production with magnification of (a) 2000 times, (b) 10000 times

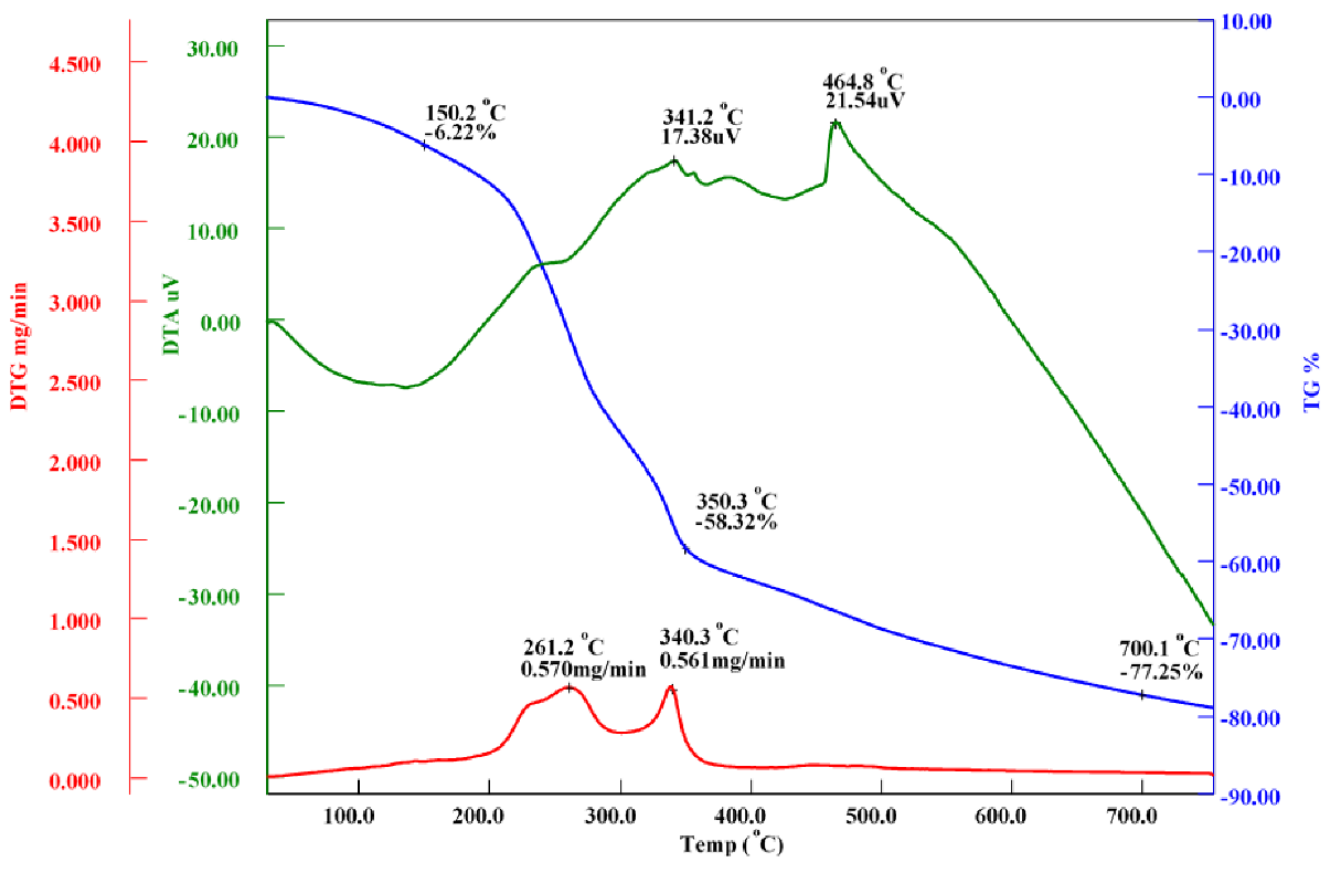

(a) 


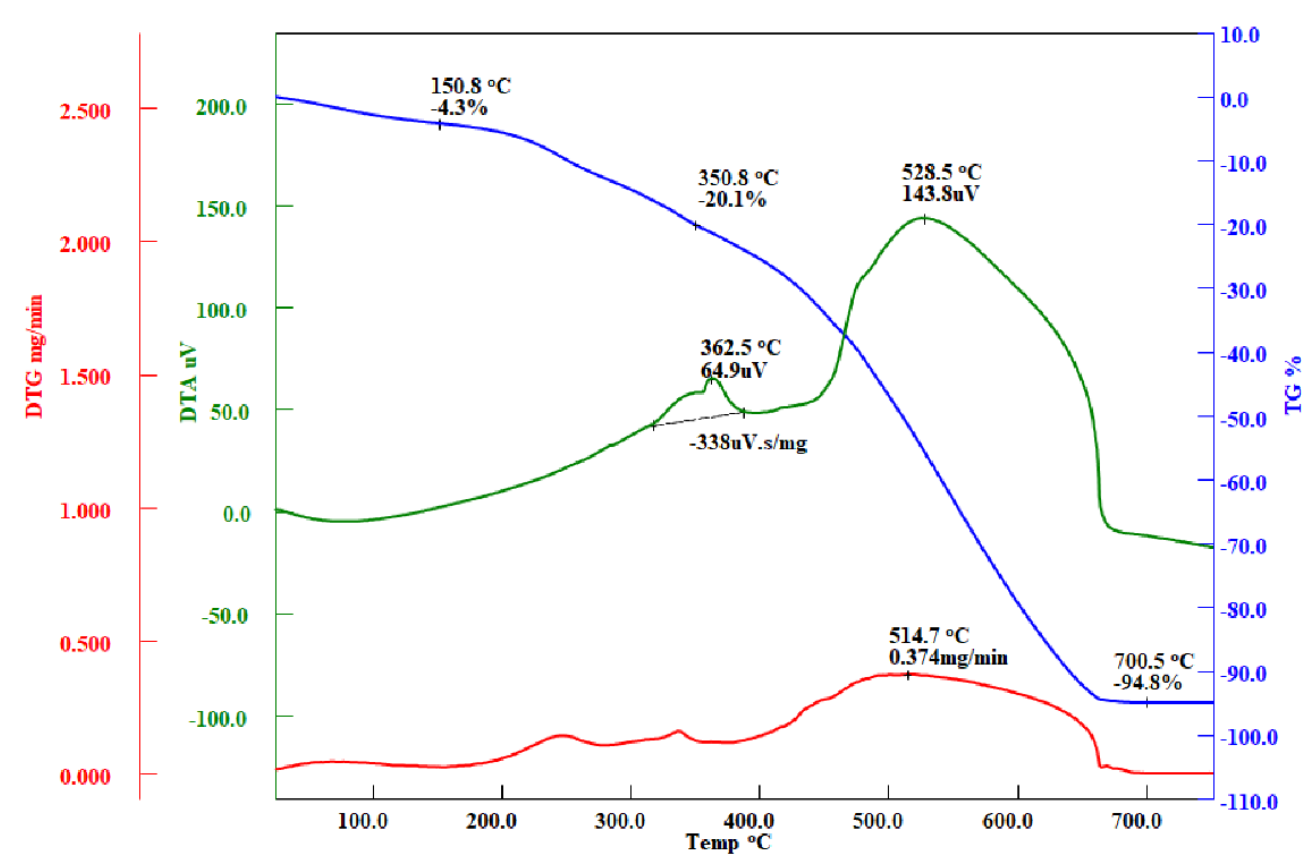

(b)

Figure 4. TG and DTG Profiles, CNS (a) and Bio-char (b)

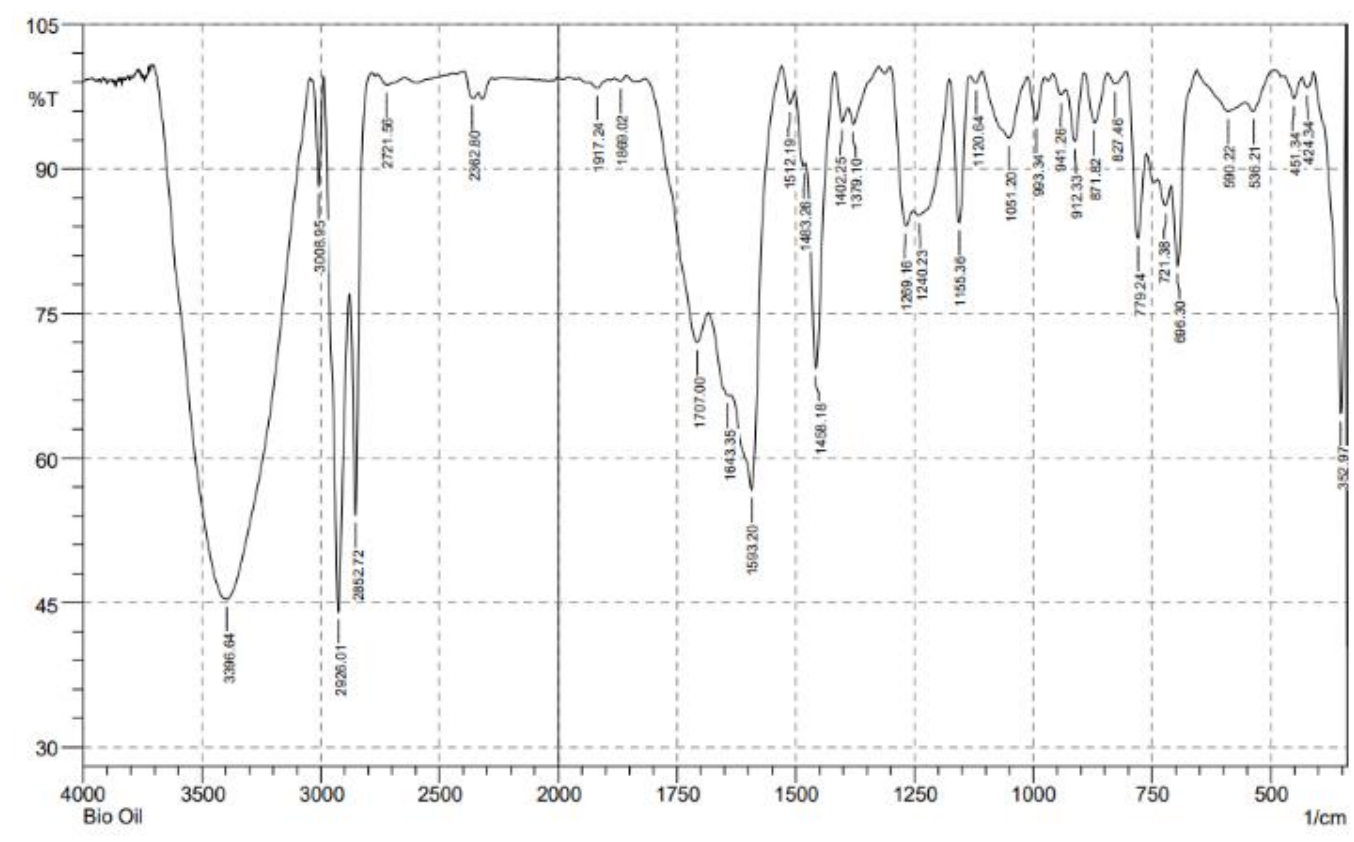

Figure 5. FT-IR Spectrum of bio-oil production

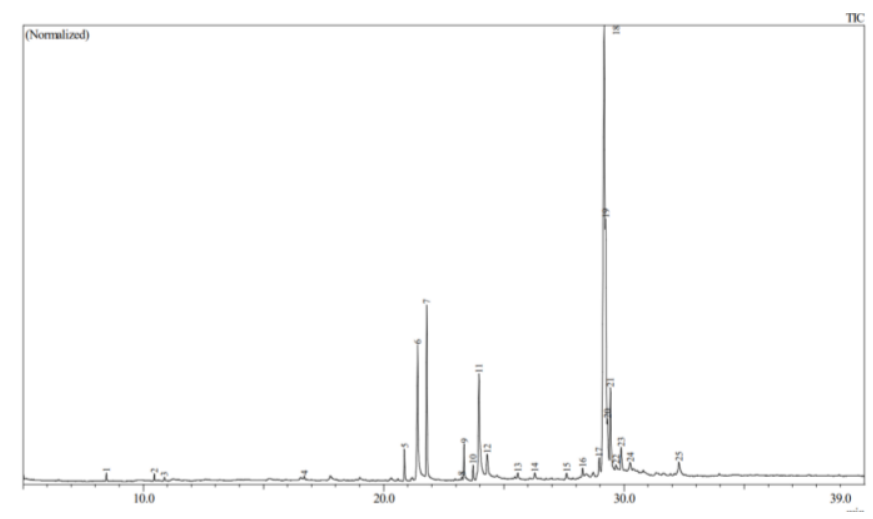

Figure 6. GC-MS of bio-oil production
$43 \%$ Bio-oil yield has density of $1.036 \mathrm{gr} / \mathrm{ml}$, viscosity of $19.5 \mathrm{cst}$ after water removing, flash point of $138^{\circ} \mathrm{C}$ and $\mathrm{HHV}$ of $21.7 \mathrm{MJ} / \mathrm{kg}$. Bio-oil chemical analysis was carried out using FT-IR representing functional group composition as shown Figure 5 and GC-MS representing type and content of bio-oil compounds as shown Figure 6. $\mathrm{C}-\mathrm{H}$ stretching at several frequencies in the range $3050-2800 \mathrm{~cm}^{-1}$ and the $\mathrm{C}-\mathrm{H}$ bending in the range $1470-1350 \mathrm{~cm}^{-1}$ are alkane compounds. Alkenes are also strongly indicated at the frequencies of 1593 and $1643 \mathrm{~cm}^{-1}$. Whereas, ketones, aldehydes, carboxylic acids are indicated in the frequency range $1750-1650 \mathrm{~cm}^{-1}$. In addition, primary, secondary and tertiary alcohol, and phenol, esters, ethers aromatic compounds are identified at frequency range $1300-950$, and $915-650 \mathrm{~cm}^{-1}$, respectively. Likewise, the absorbance peak $\mathrm{O}-\mathrm{H}$ stretching at $3396 \mathrm{~cm}^{-1}$ indicates the 
presence of polymeric $\mathrm{O}-\mathrm{H}$ and water impurities, and nitrogenous compound are at a frequency of $1512 \mathrm{~cm}^{-1}$ [34].

FT-IR results that are consistent with the GC-MS results of the bio-oil [2]. The GC-MS of the bio-oil shows about $53 \%$ phenol, $19 \%$ palmitic and oleic acid, $11 \%$ cyclobutene, $14 \%$ ethyl and methyl ester, and cyclopentene and cyclohexane in small amounts.

\section{CONCLUSION}

Pyrolysis process and products of CNS were studied at $400^{\circ} \mathrm{C}$ of microwave heating with a heating rate and heating time are $20^{\circ} \mathrm{C} / \mathrm{min}$ and 60 minutes respectively. Microwave assisted pyrolysis become an alternative methodology to produce bio-char and bio-oil for CNS. The most noteworthy feature of this method is the fast production of bio-char and bio-oil at low temperature of pyrolysis due to the homogenous heating of microwave. This study takes advantages of the potentiality of CNS to absorb microwave energy to accomplish fast and high quality of pyrolysis products. Biochar and bio-oil production are about $35 \%$ and $45 \%$, while $20 \%$ of the by products are water and bio-gas. The high hydrocarbons and less oxygen content are to be highlighted, together with high heating value and density. The porous structure of bio-char produce is potentially applied in many applications, however more analysis should be conducted to observed pore size, pore distribution and its adsorption.

\section{ACKNOWLEDGMENT}

This work is supported by PDUPT of the Indonesian Ministry of Education and Culture (Grant numbers: 1516/UN4.22/PT.01.03/2020).

\section{REFERENCES}

[1] Irena. (2020). Renewable Energy Statistics, The International Renewable Energy Agency, Abu Dhabi.

[2] IEA. (2019). Renewables-information-overview. https://www.iea.org/reports/renewables-informationoverview.

[3] World Bioenergy Association. (2019). Global Bioenergy Statistics.

[4] Akhtar, A., Krepl, V., Ivanova, T. (2018). A combined overview of combustion, pyrolysis, and gasification of biomass. Energy \& Fuels, 32(7): 7294-7318. https://doi.org/10.1021/acs/energyfuels.8b01678

[5] Rover, M., Smith, R., Brown, R.C. (2018). Enabling biomass combustion and co-firing through the use of Lignocol. $\quad$ Fuel, 211: 312-317. https://doi.org/10.1016/j.fuel.2017.09.076

[6] Nussbaumer, T. (2003). Combustion and co-combustion of biomass: Fundamentals, technologies, and primary measures for emission reduction. Energy \& Fuels, 17(6): 1510-1521. https://doi.org/10.1021/ef030031q

[7] Erol, M., Haykiri-Acma, H., Kuçukbayrak, S. (2010). Calorific value estimation of biomass from their proximate analyses data. Renewable Energy, 35: 170173. https://doi.org 10.1016/j.renene.2009.05.008

[8] Barskov, S., Zappi, M., Buchireddy, P., Dufreche, S., Guillory, J., Gang, D., Hernandez, R., Bajpai, R., Baudier,
J., Cooper, R., Sharp, R. (2019). Torrefaction of biomass: A review of production methods for biocoal from cultured and waste lignocellulosic feedstocks. Renewable Energy, 12: 624-642. https://doi.org/10.1016/j.renene.2019.04.068

[9] Hrnčič, M.K., Kravanja, G., Knez, Ž. (2016). Hydrothermal treatment of biomass for energy and chemicals. Energy, 116(2): 1312-1322. https://doi.org/10.1016/j.energy.2016.06.148

[10] Molino, A., Chianese, S., Musmarra, D. (2016). Biomass gasification technology: The state of the art overview. Journal of Energy Chemistry, 25(1): 10-25. https://doi.org/10.1016/j.jechem.2015.11.005

[11] Yaman, S. (2004). Pyrolysis of biomass to produce fuels and chemical feedstocks. Energy Conversion and Management, 45(5): 651-671. https://doi.org/10.1016/S0196-8904(03)00177-8

[12] Solar, J., Caballero, B.M., De Marco, I., LópezUrionabarrenechea, A., Gastelu, N. (2018). Optimization of charcoal production process from woody biomass waste: Effect of Ni-containing catalysts on pyrolysis vapors. Catalysts, $8(5)$ : 191. https://doi.org/10.3390/catal8050191

[13] Putra, A.E.E., Sulfiana, E., Amaliyah, N., Hayat, A. (2019). Hazardous content removal and silver nanoparticle recovery from liquid radiography waste using microwave plasma. Revue des Composites et des Matériaux Avancés, 29(6): 369-373. https://doi.org/10.18280/rcma.290605

[14] Bakri, B., Naharuddin, Putra, A.E.E., Renreng, I., Arsyad, H., Mochtar, A.A. (2018). Effect of microwave treatment on mechanical properties of coir fibers. IOP Conf. Series: Earth and Environmental Science 175: 012001. https://doi.org/10.1088/1755-1315/175/1/012001

[15] Putra, A.E.E., Amaliyah, N., Syam, M., Rahim, I. (2019). Effect of residence time and chemical activation on pyrolysis product from tires waste. Journal of the Japan Institute of Energy, 98(10): 279-284. https://doi.org/10.3775/jie.98.279

[16] Viera, F.R., Romero Luna, C.M., Arce, G., Ávila, I. (2020). Optimization of slow pyrolysis process parameters using a fixed bed reactor for biochar yield from rice husk. Biomass and Bioenergy, 132: 105412. https://doi.org/10.1016/j.biombioe.2019.105412

[17] Mullen, C.A., Boateng, A.A., Goldberg, N.M., Lima, I.M., Laird, D.A., Hicks, K.B. (2010). Bio-oil and biochar production from corn cobs and stover by fast pyrolysis. Biomass and Bioenergy, 34(1): 67-74. https://doi.org/j.biombioe.2009.09.012

[18] Moreira, R., Orsini, R., Vaz, J.M., Penteado, J.C., Spinacé, E. (2017). Production of biochar, bio-oil and synthesis gas from cashew nut shell by slow pyrolysis. Waste Biomass Valorization, 8: 217-224. https://doi.org/10.1007/s12649-016-9569-2

[19] Nam, N.H., Orsini, R., Vaz, J., Penteado, J.C., Spinacé, E.V. (2020). Pyrolysis of cashew nut shell: A parametric study. Vietnam Journal of Chemistry, 58(4): 506-511. https://doi.org/10.1002/vjch.202000015

[20] Tsamba, A.J., Yang, W., Blasiak, W. (2006). Pyrolysis characteristics and global kinetics of coconut and cashew nut shells. Fuel Processing Technology, 87: 523-530. https://doi.org/10.1016/j.fuproc.2005.12.002

[21] Yin, C. (2012). Microwave-assisted pyrolysis of biomass for liquid biofuels production. Bioresource Technology, 
120:

273-284

http://dx.doi.org/10.1016/j.biortech.2012.06.016

[22] Motasemi, F., Afzal, M.T. (2013). A review on the microwave-assisted pyrolysis technique. Renewable and Sustainable Energy Reviews, 28: 317-330. https://doi.org/10.1016/j.rser.2013.08.008

[23] Zhao, X., Wang, M., Liu, H.Z., Li, L.Z., Ma, C.Y., Song, Z.L. (2012). A microwave reactor for characterization of pyrolyzed biomass. Bioresource Technology, 104: 673678. https://doi.org/10.1016/j.biortech.2011.09.137

[24] Weber, K., Quicker, P. (2018). Properties of biochar. Fuel, 217:

240-261 http://doi.org/10.1016/j.fuel.2017.12.054

[25] Antal, M.J., Grønli, M. (2003). The art, science, and technology of charcoal production. Ind Eng Chem Res., 42(8): 1619-40. http://doi.org/10.1021/ie0207919

[26] Senthilkumar, P., Ramalingam, S., Abhinaya, R., Kirupha, S.D., Vidhyadevi, T., Sivanesan, S. (2012). Adsorption equilibrium, thermodynamics, kinetics, mechanism and process design of zinc(II) ions onto cashew nut shell. Canadian Journal of Chemical Engineering, $\quad 90(4)$ : 973-982. https://doi.org/10.1002/cjce.20588

[27] Ahmadou, A., Brun, N., Napoli, A., Durand, N., Montet, D. (2019). Effect of pyrolysis temperature on ochratoxin A adsorption mechanisms and kinetics by cashew nut shell biochars. Journal of Food and Technology, 4(7): 877-888. https://doi.org/10.25177/JFST.4.7.RA.565
[28] Nuithitikul, K., Phromrak, R., Saengngoen, W. (2020). Utilization of chemically treated cashew-nut shell as potential adsorbent for removal of $\mathrm{Pb}$ (II) ions from aqueous solution. Scientific Reports, 10(1): 1-14. http://doi.org/10.1038/s41598-020-60161-9

[29] Tsamba, A.J., Yang, W., Blasiak, W. (2006). Pyrolysis characteristics and global kinetics of coconut and cashew nut shells. Fuel Processing Technology, 87(6): 523-530. http://doi.org/10.1016/j.fuproc.2005.12.002

[30] Ábrego, J., Plaza, D., Luño, F., Atienza-Martínez, M., Gea, G. (2018). Pyrolysis of cashew nutshells: Characterization of products and energy balance. Energy, 158: 72-80. http://doi.org/10.1016/j.energy.2018.06.011

[31] Brebu, M., Vasile, C. (2010). Thermal degradation of lignin - a review. Cellul Chem Technol, 44(9): 353-6.

[32] Yang, H., Yan, R., Chen, H., Lee, D.H., Zheng, C. (2007). Characteristics of hemicellulose, cellulose and lignin pyrolysis. $\quad$ Fuel, 86(12-13): 1781-8. https://doi.org/10.1016/j.fuel.2006.12.013

[33] Watkins, D., Nuruddin, M., Hosur, M., Tcherbi-Narteh, A., Jeelani, S. (2015). Extraction and characterization of lignin from different biomass resources. J Mater Res Technol., $\quad 4(1)$ : 26-32. https://doi.org/10.1016/J.JMRT.2014.10.009

[34] Das, P., Sreelath, T., Ganesh, A. (2004). Bio oil from pyrolysis of cashew nut shell-characterisation and related properties. Biomass and Bioenergy, 27(3): 265-275. https://doi.org/10.1016/j.biombioe.2003.12.001 